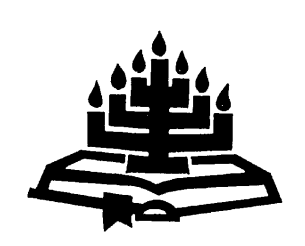

\title{
Preaching as reframing of perspective
}

\author{
J.H. Cilliers \\ Department of Practical Theology and Missiology \\ University of Stellenbosch \\ STELLENBOSCH \\ E-mail: jcilliers@sun.ac.za
}

\begin{abstract}
Preaching as reframing of perspective

This article takes as point of departure the notion that preaching represents a form of reframing of perspective. Cognisance is taken of Calvin's understanding of faith as perceiving, as well as Capps' (1990) reintroduction of the idea of reframing. This is followed up by a brief look at Paul's reframing of the concepts "foolishness" and "wisdom", as well as an excursion into the world of art, particularly surrealism as possible homiletic collaborator. Some implications are drawn for preaching, under the headings: the preacher, congregation, the Biblical text and God as reframer.
\end{abstract}

\section{Opsomming}

\section{Prediking as heroriëntasie van perspektief}

Hierdie artikel neem as vertrekpunt die gedagte dat prediking 'n vorm van heroriëntasie van perspektief verteenwoordig. Daar word kennis geneem van Calvyn se wyse van verstaan van geloof as waarneming, asook Capps (1990) se sienings oor heroriëntasie. Dit word opgevolg deur 'n bondige blik op Paulus se herinterpretasie van die konsepte "dwaasheid" en "wysheid", asook 'n ekskursie in die wêreld van die kuns, in besonder die surrealisme, as 'n moontlike homiletiese kollaborateur. Enkele implikasies vir die prediking word uitgespel onder die opskrifte: die prediker, gemeente, Bybelteks en God as rolspelers in die proses van heroriëntasie.

\section{Introduction: preaching as reframing of perspective}

It is indeed a privilege to contribute towards this celebration of Ben de Klerk's theological legacy. I would describe him as a humble prophet. In many of his writings, he was ahead of his times and also 
his ecclesiological context, for instance in his articles on the ritual dimensions of liturgy (De Klerk, 1999; 2001; 2002). One could say that he was continuously striving to reframe the perspectives of his church, colleagues, and society, but never in an intrusive manner. His soft-spoken convictions will have an enduring impact.

In the light of the above-mentioned, I intend to focus in this article on the role that preaching can play in the reframing of perspective. Preaching is indeed all about creating, but also recreating (reframing) of perspective (Campbell \& Saunders, 2000:30). To preach is to see and to invite others to see (Cilliers, 2004:64). The art of preaching is inter alia about the discernment of "signs of transcendence", epiphanies of deeper dimensions even in the small things of life (Weyel, 2007:209-211; cf. also Berger, 1997:205).

It is interesting to note that the great Reformer, Calvin, often spoke about the knowledge of faith as a way of perceiving. For him knowledge entailed more than just taking note of the state of affairs, but rather an attentive perception of life (the French word that he used being l'entendement; Neven, 2009:80). Perception is the space where reality enters a human being. In this regard Calvin was fond of the metaphor of a mirror. Some scholars, however, are of the opinion that he used it obsessively (Neven, 2009:80). The metaphor of the mirror was, of course, well known and beloved at the time among philosophers and authors - reminiscent of the way that Paul uses it in describing the nature of our knowledge in this dispensation (1 Cor. 13:12). The mirrors of antiquity revealed, but also concealed; it offered a dim reflection of reality. For Calvin it meant that it brought into picture images of God, albeit indirectly and vaguely, that would otherwise have remained unknown, and when in direct light, mirrors often shock, call for attention, and create fascination (Neven, 2009:80, 81).

For Calvin the metaphor of the mirror could be linked to certain places, facts, experiences, and histories that function as mirror of God - inviting us to view his activity, even if it is in an indirect and incomplete way. In other words, the mirror represents the myriad of ways, the palette of earthly media, through which the multi-colored knowledge of God can be reflected, in order to create and nourish our faith (Van der Kooi, 2002:22, 23).

It is important to understand that our perspectives on God, and therefore on life, can easily become narrow. We are often blinded, or at least we become short-sighted. Our images of God need to be constantly revisited in order to be revisioned. This is true not only on 
an individualistic level, but also in terms of our tendency towards shared blindness and group myopia. A painful reminder of this is the fact that the ideology of apartheid, for instance, excelled in structured short-sightedness, if not structural blindness. The frame from which it viewed reality (God and humanity) was that of an enclave mentality. People were indoctrinated (structurally blinded) to see no further than their own (nationalistic, cultural, religious, especially ethnic) horizons. The borders formed by this ideology obstructed any view that one could have on alternatives - the only view that "we" could have on "them" was that of "us" against the "enemy" (Cilliers, 2006:63-76). Identity ("we"/"us") was formed on the basis of ethnic categories. The tendency was to see everything in black and white.

Preaching can play an important role in adding colour to our perspective - in opening up vistas never seen before, in painting rainbows before our eyes. This art of revisioning of reality could also be called reframing. Capps (1990:12), who reintroduced the concept of reframing, speaks about the difference between a first-order and a second-order change, and maintains that the former occurs within a given system (although the system as such remains unchanged), while the latter transforms the system itself. Reframing means

... to change the conceptual and/or emotional setting or viewpoint in relation to which a situation is experienced and to place it in another frame which fits the 'facts' of the same concrete situation equally well or even better, and thereby changes its entire meaning (Capps, 1990:17).

This implies a theological reconfiguration of the existing, in such a way that something distinctly new is born, but not without the old. It is the art to do and say the same things in a (sometimes completely) different way, of using the old to say and do the new by means of juxtaposition (Lathrop, 1993:33).

An interesting parallel could be drawn between the concept of reframing and the sixteenth-century Reformation. The historical and philosophical roots of reframing - at least as Capps (1990) implements it - are planted firmly in the discipline of pastoral care. The presupposition is that reframing leads to pastoral change (reformation), and vice versa. It could be argued that the basic principles of the act of reformation and the act of reframing are the same, despite historical and contextual discontinuities. In my opinion, the Reformation was all about this dynamic interaction between reframing (seeing new) and being reformed (becoming new). The Reformation 
was a pastoral movement of reform, as much as it was an act of reframing.

The frame - one could say the paradigm - through which reality is viewed, is indeed of the utmost importance. We could indeed say that this frame mediates (the viewer's understanding of) meaning. It could therefore also reveal a church's and a preacher's theology (or lack thereof) that lies behind the way in which observation takes place. The frame evokes and replicates the structure of the theology that has given birth to it, and in the process also reveals the basic anthropology underlining it. In a nutshell: the frame through and within which we observe reality, reveals and forms our images of God and humanity. Preaching is all about this framing and reframing of our perspectives - ultimately about being reframed by the actions of God that opens up dimensions far beyond what we could imagine (cf. 4.4).

\section{Reframing within the perspectives of foolishness and wisdom}

There are of course many images of, and perspectives on God. God has many faces (Durand, 2007:4). I am of the opinion that the presupposition that forms the basis of all these multifaceted images and perspectives lies in the notion of paradox, i.e. in the fact that God is present in this world, and reveals Himself sub contrario (in contradictions). Or in the words of Berkhof (1979:54):

He can be present in his world only as a stranger, the suffering servant, the crucified one. The concept of paradox is suitable here: God is present contrary to (para) the appearance (doxa) of the opposite.

This is of paramount importance for the basic structure of preaching and, in my opinion, forms the leitmotiv of preaching that intends reframing.

God's presence in this world, the "signs of transcendence", and epiphanies of deeper dimensions even in the small things of life (Weyel, 2007:209-211; cf. also Berger, 1997:205), is often, if not always, surprising and even shocking to us in the sense that it contradicts our understandings (images) of who God is or should be. The fact that God has many faces, as seen from the (selective, impeded, relative) perspective of human perception and imagination, opens up the possibility of idolatry. Therefore, God must pneumatologically reframe our images and even shatter the restricted, self- 
serving frames through which we tend to look at God. We are inclined to construct safe and manageable images of God that do not challenge and expose the illusion of our, often destructive, frames of perspective. Therefore, framing or reframing cannot be left in our hands alone, as the result may be - no matter how many times reframing takes place - the creation of a more sophisticated illusion. We seem to fall prey to a perpetual destructive or domesticated framing of who God is. Even from the beginning the message of the gospel was misunderstood and contradicted our expectations. In fact, many thought, and still do, that such a strange gospel in which the powerlessness of the cross and not a conventional, powerful God is central, could indeed be described as absurd and ludicrous, and become a stumbling block and irritation to many (Cilliers, 2004:4).

Many homileticians, like for instance Campbell (2008:1-19), Cilliers (2004:3-5), Grözinger (2008:96), et cetera, have traced the roots of Paul's description of the foolishness of preaching back to his letters to the Corinthians, for example, when he states:

For the message of the cross is foolishness to those who are perishing, but to us who are being saved it is the power of God ... For since, in the wisdom of God, the world did not know God through wisdom, God decided, through the foolishness of our proclamation, to save those who believe. (1 Cor. 1:18, 21.)

And later on, in the same vein:

I think that God has exhibited us apostles as last of all, as though sentenced to death, because we have become a spectacle to the world, to angels and to mortals. We have become fools for the sake of Christ ... (1 Cor. 4:9-10).

With utterances like these Paul radically deconstructs (reframes) some basic notions of his times, especially in terms of (God's) power and wisdom. While the Jews were looking for signs, which in their tradition often meant a direct and clear revelation of God or the actions of (powerful) people that could perform wonders and conjure up signs, the Greeks were yearning for wisdom, i.e. the power to discern and lead, without wavering. Greek wisdom stemmed from the philosophical and theoretical reflection on the origin and destination of humanity. It entailed being able to explain the visible and invisible powers that influence life, history and society. In effect wisdom was understood as a form of power; knowledge equaled power (Goetzmann, 1978:1026). 
The cross is, however, all about powerlessness, which both Jews and Greeks would deem foolishness. This is the central scandal (skandalon) of the cross: Christ the crucified is the radically weak One, and those that follow him must of necessity be weak - at least in the eyes of those that seek power and wisdom.

The foolishness of the cross does not mean that it is unintelligible, or that our faith in it presupposes a sacrificium intellectus. It is rather a different, inverted, and reframed form of power and wisdom. The foolishness of God (to mōron tou theou) is not an attribute of God, but indicates the way in which He reveals Himself in Christ - as powerless. That is why Paul in this regard often speaks in terms of paradoxes: we should become foolish, in order to become wise; and when we are weak, we are strong (1 Cor. 3:18; 2 Cor. 12:10; Goetzmann, 1978:1026). These are indeed the hallmarks of the preacher as fool, the moron for Christ: foolishness and powerlessness - which in fact entails wisdom and power of a different, paradoxical order.

This radical deconstruction and reframing of power and wisdom has fundamental implications on a variety of levels. Of specific importance for us is the impact that this has on preaching. Preaching presupposes (and conveys) certain God images. Preaching could, however, hardly be understood without its connection to the church, and the church in turn should not be understood without its connections to society. The presupposition here is that preaching, being imbedded in the church, could have a transformative impact on society, in the sense that it helps to create, or deconstruct, certain God images.

Briefly put: the radical deconstruction and reframing that Paul articulates has fundamental implications on theological, homiletical, ecclesiological, and societal level - especially as far as the notion of "power" is concerned. Preaching, understood as the foolishness of inverted power could indeed be instrumental in aiding the church to deconstruct and reframe existing God images in such a way that its message of the cross discloses and shatters illusionary wisdom and mediates new meaning within a society that finds itself in flux $-\mathrm{a}$ society that often tends to misunderstand and misappropriate power.

\section{The art of reframing: visiting a (seemingly unlikely) collaborator}

Art, if it is good, is all about reframing. It offers new insights in reality, a new take on things. Art often challenges our conventional 
perspectives, and shocks the status quo of our individual or societal blindness. It invokes us to look again, or to change our viewpoint (the co-ordinates from which we perceive).

The relationship between art and reframing, of course, brings with it an array of questions. Should a distinction for instance be made between art and art? Should the difference between the vision of a Christian artist (through faith perception) and a "secular" artist be noted, theologically speaking, as relevant in defining the contribution of (good) art in the process of reframing reality? Of course the eyes of an artist that does not necessarily view life through a Christian lens can surely open up new perspectives, but there can probably also be made a case that art in some instances can proceed from corrupted vision and produce a perspective on reality full of deception or cause perception to deteriorate into the unauthenticity of kitsch - the latter, however, being true of "Christian" and "secular" art. Whatever distinctions one makes here, as point of departure we could hypothesise that (good) art questions the validity of the mirrors that we use in viewing life.

Nowhere is this illustrated more dramatically than in the art form of surrealism. Surrealism originated in France in the 1920s, and its aim was to resolve the "previously contradictory conditions of dream and reality", according to its main theorist, André Breton (Adam \& Cleave, 1996:506). Surrealists painted unnerving and seemingly illogical scenes, often making use of collections or scenes from everyday life, allowing the unconscious to express itself (Berman, 1983: 21). Surrealism, like its forerunner, Dadaism, protested against the snobbery and traditionalism of the art establishment, and warned against a narcotic stupor within aesthetics. As such it represented a type of anti-art, for the sake of art (Bohren, 1980:60). The surrealistic movement included renowned artists such as Bellmer, Brauner, Dalí, Delvaux, Ernst, Kahlo, Gorky, Klee, Preller, and many others (Berman, 1975:129). 


\section{Part of Melting clocks (Salvador Dalí, 1931)}

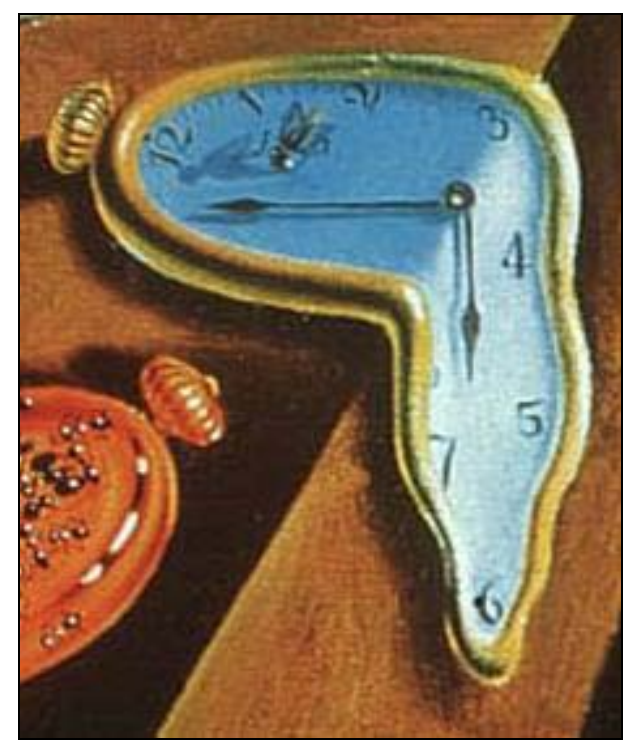

One of the best known surrealists would probably be Salvador Dalí. His creation of a "melted clock", as seen above (and being part of a bigger painting, called The persistence of memory, or Melting clocks, 1931), illustrates the intentions of surrealism in an evocative manner. Normally watches do not look like this. They are rather rigid objects, signifying that (our understanding of) time is set, and cannot be altered. Time cannot be bent - at least not in our earthly experience of it. Therefore we are victims of time; we are pulled along in its wake. Time neither waits for, nor obeys anyone. Tempus fugit time flies; constantly escaping from our grasp. It indeed seems as if time governs our lives, every minute detail of it, whether we accept it or not.

But Dalí challenges us to revisit our understanding of time. He reminds us that clocks are human inventions, and that we need not be victims of time. Time becomes pliable, and is no longer rigid or deterministic. Time opens up spaces for existence, and should not be seen as the enemy of existence. Time is a gift, not a threat.

Whatever way one chooses to interpret Dalís melted clock, the point is clear: he invites us to reframe, to step into an alternative space of co-ordinates, to try out a different viewpoint. He subverts our conventional usage of watches and clocks. He says: take another look. Discern deeper and further - perhaps this will help you to come closer to a better, more humane view on time.

Perhaps we could say that the reframing of surrealist art consists of three stages. The first is position, or status quo (stasis); the second 
is questioning of this position, of alienating that which we thought we knew (anti-stasis); and the third is the possibility of a re-evaluation, and ultimately a reconfiguration of the original position, in other words a new position, surpassing the original (meta-stasis).

I am not advocating here that all preachers should become surrealists or Dadaists. Of course there were also flaws and excesses in this movement. It seemed to be strong in the area of anti-stasis, without really offering a meta-stasis, or at best an embryonic form thereof. But they, more than anyone else - at least in the European culture of the 1930s - understood the notion and need of reframing. In this sense they represent a valuable homiletic collaborator.

I now briefly attend to some implications for preaching.

\section{Homiletical implications}

\subsection{The preacher as reframer}

Preaching is about discerning signs of transcendence in everyday life. This means, on the one hand, that the preacher should be sensitive for, and observant of life. Preachers should discern the religious dimensions of people's experiences in space and time. Experiences, also those religious in nature, exist in space and time. However, space and time, within which these experiences take place, are always particular spaces and particular times (Grözinger, 2005:1). This means that preachers should dwell within the spaces and times of those to whom they intend to preach. If preachers are to connect to people, they will have to connect to the particular (religious) experiences that these people have.

On the other hand, this entails that preachers are called to discern these experiences as religious experiences, to interpret them as such to congregants. The preacher's task is inter alia to reframe these experiences in such a way, using the lens (or mirror) of Scripture, so that people might indeed recognise this perhaps seemingly mundane experience as one with profound meaning. Experiences must be named, and for that the preacher needs the language of experience (Grözinger, 2005:2). The best way to name experience is to talk to others about our own experiences. Preachers cannot, and indeed should not, speak in an abstract manner. They are called to continuously seek words that describe experiences that describe life. It is a continuous homiletic process, creating appropriate language of experience. Language of experience can act as tools for reframing of perspective. 


\subsection{The congregation as reframer}

In order to find language of experience, the preacher needs to listen to (the experiences of) the congregation. Since the 1970s there has been a strong movement in homiletics towards a "hearer friendly" approach, with people like Craddock (1971:25) advocating an inductive method that seeks to unlock the experiences of the congregation in such a manner that preaching is indeed meaningful to them. Lange (1976:34) spoke about the "homiletical situation" in which the hearer becomes the actual theme of the sermon, if preaching is to make a difference. Since Craddock and Lange many homileticians like Lowry (1980:76), Buttrick (1987:294), Hilkert (1998:55), and others have pleaded for a form of preaching that in fact connects to congregant's experiences of life.

Although these notions are of paramount importance, I am of the opinion that preaching is more than just a connection to, or even clarification of experiences. The focus on the hearer - Bohren (1980:444) calls it homiletics' beloved child, being born out of a massive adaptation to society - should not become exclusive. Experiences could be wrong and detrimental. They need to be interpreted, but often also directed or transformed. This is what is meant by reframing. Looking at life's experiences through the lens (or mirror) of Scripture reminds us that there is an alternative - a meta-stasis that what we deemed to be wise, could in fact be foolish, and vice versa. The art of preaching lies therein that the preacher reframes life's experiences in such a way that congregants can follow suit; that they in fact also become reframers. Or in other words, preaching is the art of discovering (as preachers and congregants) that life in its fullest sense of the word is connected to God; is experienced coram deo.

\subsection{The Biblical text as reframer}

The Bible is filled with images that reframe reality. It happens as follows: firstly, there is a moment of orientation, in which you recognise certain familiar things in the image, the image addresses something of your reality (one could say: stasis). Then the phase of disorientation follows (not necessarily sequentially; mostly simultaneously), when the image questions your reality and, in a sense, overturns it (anti-stasis).

Biblical images mostly work as follows: a familiar metaphor suddenly becomes challenging, works subversively on the status quo - like the small piece of yeast becoming an image of an inexorable king- 
dom (Matt. 13:33). Scriptural images are indeed often contra-images - images that give us an "imaginative shock", which present to us as a "counter-as", the dissimilar "like" of the kingdom (Riegert, 1990:7274; cf. also Brueggemann, 1993:15). After the disorientation, a phase of reorientation follows in which the image opens the prospects of new possibilities and worlds to us, and functions as a world-creating power (meta-stasis).

Texts often serve as counter-testimonies or cross-examinations of our core beliefs. They more than often reveal sides or images of God that hardly fit with conventional theological and sermonic language. Biblical texts act as mirrors for reframing, reflecting the many acts and many faces of God.

\subsection{God as reframer}

Ultimately, on the cross and through the resurrection, God is the One who reframes our understanding of who God is. We often fall prey to certain notions of God's power - notions that have become fixed and set in our traditions, relentless like our rigid, time-keeping clocks. We often tend to try and conserve our experiences of God as if they are final and complete.

It is a sad fact of history that the church, and perhaps especially the church, suffers from a tendency to fall prey to ideologies of power, which Keshgegian (2000:27) describes as kyriarchy ("the multiple and complex systemic grading of dominations, subordinations, and power arrangements"). The church, reckoning with the "power" of God, often tends to mistake itself (structures, officials, theology) as the final knowledge, if not God Himself. It often positions itself in a dominating and controlling position within the networks and grading of those that have power, and those deemed to be without power. It often marginalises, instead of siding with the marginalised.

The gospel of foolishness offends us deeply, especially if we have grown accustomed to phrases like the omnipotence, omniscience, and omnipresence of God. Perhaps notions like these, or at least our understanding of them, are indeed still antiquated influences of male fantasies about power, or remnants of a philosophical construction that created a metaphysical God that has been sterilised against all that is human and therefore vulnerable (Schiwy, 1995:19, 48).

Preaching as reframing challenges our fixated images of God. It melts down our theologies, not unlike Dalí's melted clock. It reminds 
us constantly that our experiences of God, our theologies and preaching on God, are but beginnings. It aids us in looking in and through the reframing mirror, knowing that God's revelation is simultaneously God's concealment, and that God's concealment is simultaneously God's revelation (1 Cor. 13:12). It reminds us that our frames are not finalities.

\section{List of references}

ADAM, B.C.V. \& CLEAVE, S.S. 1996. The art book. London: Phaidon.

BERGER, P.L. 1997. Redeeming laughter: the comic dimension of human experience. Berlin: De Gruyter.

BERKHOF, H. 1979. Christian faith. Grand Rapids: Eerdmans.

BERMAN, E. 1975. The story of South African painting. Cape Town: Balkema.

BERMAN, E. 1983. Art and artists of South Africa: an illustrated biographical dictionary and historical survey of painters, sculptors and graphic artists since 1875. Cape Town: Balkema.

BOHREN, R. 1980. Predigtlehre. München: Kaiser.

BRUEGGEMANN, W. 1993. The Bible and postmodern imagination: texts under negotiation. London: SCM.

BUTTRICK, D. 1987. Homiletic: moves and structures. Philadelphia: Fortress.

CAMPBELL, C. 2008. The foolishness of preaching: ethical reflections. Paper delivered at the eighth International Conference of the Societas Homiletica, held in Copenhagen, Denmark, 19-25 Jun. 2008. (Unpublished.)

CAMPBELL, C. \& SAUNDERS, S.P. 2000. The word on the street: performing the Scriptures in the urban context. Grand Rapids: Eerdmans.

CAPPS, D. 1990. Reframing: a new method in pastoral care. Minneapolis: Fortress.

CILLIERS, J.H. 2004. The living voice of the gospel: revisiting the basic principles of preaching. Stellenbosch: Sun Press.

CILLIERS, J.H. 2006. God for us? An analysis and evaluation of Dutch Reformed preaching during the apartheid years. Stellenbosch: Sun Press.

CRADDOCK, F.B. 1971. As one without authority. Nashville: Abingdon.

DE KLERK, B.J. 1999. Skuldbelydenis en versoening as kommunikatiewe handeling in die liturgie van die samekoms van die lewe. Praktiese teologie in Suid-Afrika, 14(1):23-45.

DE KLERK, B.J. 2001. Wisselwerking tussen liturgie en kultuur in SuidAfrikaanse konteks: enkele vertrekpunte. Praktiese teologie in Suid-Afrika, 16(2):57-75.

DE KLERK, B.J. 2002. Liturgie, transformasie en die Afrika Renaissance. (In Barnard, M. \& Schuman, N., reds. Nieuwe wegen in de liturgie: de weg van de liturgie - een vervolg. Zoetermeer: Meinema. p. 50-62.)

DURAND, J. 2007. The many faces of God: highways and byways on the route towards an orthodox image of God in the history of Christianity from the first to the seventeenth century. Stellenbosch: Sun Press.

GOETZMANN, J. 1978. Wisdom, folly, philosophy. (In Brown, C., ed. Dictionary of New Testament Theology. Vol. 3. The Paternoster Press. p. 10231026.) 
GRÖZINGER, A. 2005. The way of experience: preaching as shaping experience in a world of conflict. Singapore: Gospel Works. (Studia Homiletica 5.)

GRÖZINGER, A. 2008. Homiletik: Lehrbuch Praktische Theologie. Band 2. München: Gütersloh.

HILKERT, M.C. 1998. Naming grace: preaching and the sacramental imagination. New York: Continuum.

KESHGEGIAN, F.A. 2000. Redeeming memories: a theology of healing and transformation. Nashville: Abingdon.

LANGE, E. 1976. Predigen als Beruf. Stuttgart: Kreuz.

LATHROP, G.W. 1993. Holy things: a liturgical theology. Minneapolis: Fortress.

LOWRY, E.L. 1980. The homiletical plot: the sermon as narrative art form. Atlanta: John Knox.

NEVEN, G.W. 2009. De kwintessens van Calvijn: het Calvinistisch ongemak. (In Brouwer, R.R., De Leede, B. \& Spronk, K., reds. Calvijn als erflater en provocator van het Nederlandse protestantisme. Kampen: Kok. p. 73-97.)

RIEGERT, E.R. 1990. Imaginative shock: preaching and metaphor. Burlington: Trinity Press.

SCHIWY, G. 1995. Abschied vom allmächtigen Gott. München: Kösel.

VAN DER KOOI, C. 2002. Als in een spiegel: God kennen volgens Calvijn en Barth. Kampen: Kok.

WEYEL, B. 2007. Predigt und Alltagskunst: Wilhelm Genazino und der poetische Blick auf das Leben. (In Gräb, W., Hermann, J., Kulbarsch, L., Metelmann, J. \& Weyel, B., Hrsg. Religion - Ästhetik - Medien. Band 2: Ästhetik und Religion: interdisziplinäre Beiträge zur Identität und Differenz von ästhetischer und religiöser Erfahrung. Frankfurt am Main: Peter Lang. S. 207-215.)

\section{Key concepts:}

preaching

reframing

surrealism

Kernbegrippe:

heroriëntasie

prediking

surrealisme 
